\title{
Characteristics of the antitrypsin activity of human serum ${ }^{1}$
}

\author{
PETER T. ROWLEY AND DAGMAR OETTE \\ From the Departments of Medicine and Pediatrics and the Division of Genetics, University of Rochester \\ School of Medicine and Dentistry, Rochester, New York
}

SYNOPSIS The antitrypsin activity of human serum was studied as a function of $p \mathrm{H}$, preincubation of serum with trypsin, and the concentrations of substrate, trypsin, and serum. Maximal activity was observed between $p \mathrm{H} \mathrm{8.0}$ and 8.3. Activity was enhanced by preincubation of serum with trypsin, and reduced by high concentrations of trypsin and substrate. Percentage inhibition was a sigmoid function of $\log$ serum concentration. Theoretically, this relationship is expected of a reversible enzyme inhibitor; reversibility was demonstrated by dilution of enzyme serum mixtures. Practically, this relationship limits accurate antitryptic activity assay to the $25-75 \%$ inhibition range.

About $90 \%$ of the antitrypsin activity of human serum lies in a $\alpha_{1}$-globulin fraction ( $\alpha_{1}$-antitrypsin) (Jacobsson, 1955). The structure of this protein is determined by a genetic locus believed to have at least 11 alleles (Daughaday, Eradio, and Pierce, 1971). The genotype $Z Z$ is associated with panacinar pulmonary emphysema and with juvenile cirrhosis (Guenter, Welch, and Hammarsten, 1971). Whether disease is associated with other genotypes is in dispute (Guenter $e t$ al, 1971). Resolution will require clinical study of a large number of individuals of known genotype. Complete genotyping at present requires crossed antigen-antibody electrophoresis (Fagerhol, 1969), a time-consuming procedure. Published methods for measurement of serum trypsin inhibitory capacity do not reliably separate the commonest genotype (MM) from the commonest $Z$ heterozygote (MZ) (Fagerhol, 1969). Our long-range aims are developing simpler genotyping methods and clarifying the pathogenesis of lung injury. As a preliminary study, we have undertaken a characterization of human serum antitrypsin activity.

\section{Methods}

Sera previously genotyped by crossed antigenantibody electrophoresis (Fagerhol, 1969) were

\footnotetext{
${ }^{1}$ The research upon which this publication is based was performed at the University of Rochester School of Medicine and Dentistry and pursuant to contract no. NIH-71-2221 with the National Institutes of Health, Department of Health, Education, and Welfare.

Received for publication 17 November 1972.
}

stored at $-20^{\circ} \mathrm{C}$. Sera of genotype MM (normal) were used for all experiments except where indicated otherwise. Bovine pancreatic trypsin, twice crystallized, was obtained from Worthington Biochemical Corporation. Trypsin solutions in $10^{-3} \mathrm{M} \mathrm{HCl}$, $1 \mathrm{mg}$ per $\mathrm{ml}$, were stored at $4^{\circ} \mathrm{C}$ for one week. Tosyl-L-arginine methyl ester (TAME) and benzoylL-arginine ethyl ester (BAEE) were obtained from Mann Research Laboratories, New York, NY. Serum antitrypsin activity was determined by adding to $0.96 \mathrm{ml}$ of $46 \mathrm{mM}$ Tris- $\mathrm{Cl}(p \mathrm{H} \mathrm{8.0)}-11.5$

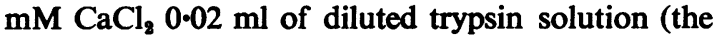
above $1 \mathrm{mg} / \mathrm{ml}$ solution diluted $1: 20$ ) and $0.02 \mathrm{ml}$ of a 1:60 dilution of serum. After 15 minutes at $25^{\circ} \mathrm{C}$ (preincubation), $0.02 \mathrm{ml}$ of $80 \mathrm{mM}$ TAME was added and the change in OD at $247 \mathrm{~nm}$ determined. The optical density change was recorded to provide initial rates.

A Gilford spectrophotometer (model 220), automatic cuvette positioner (model 210), and recorder (model 6040) provided the simultaneous recordings of four reactions. The reaction rate was linear for at least five minutes. A control, identical except for the absence of serum, was run simultaneously. Percentage inhibition was calculated by dividing the difference between the control rate and the rate in the presence of serum by the control rate.

\section{Results and Discussion}

The trypsin inhibitory activity of human serum was affected by various features of the assay. These 
included the $p \mathrm{H}$, the period of preincubation of serum with trypsin, the concentration of substrate, and the concentration of trypsin.

The $p \mathrm{H}$-activity curves with and without serum were similar (Fig. 1). The $p \mathrm{H}$ optimum for both is between 8.0 and 8.3 . Between $p \mathrm{H} \mathrm{7.0}$ and 8.5 antitrypsin activity rises with increasing $p \mathrm{H}$. The $p \mathrm{H}$ activity curve of human serum antitrypsin resembles that of bovine pancreatic trypsin inhibitor (Laskow-

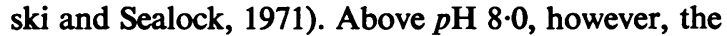
known alkaline instability of trypsin complicates interpretation of results. Therefore, for routine assay, $p \mathbf{H ~} 8.0$ is a satisfactory choice.

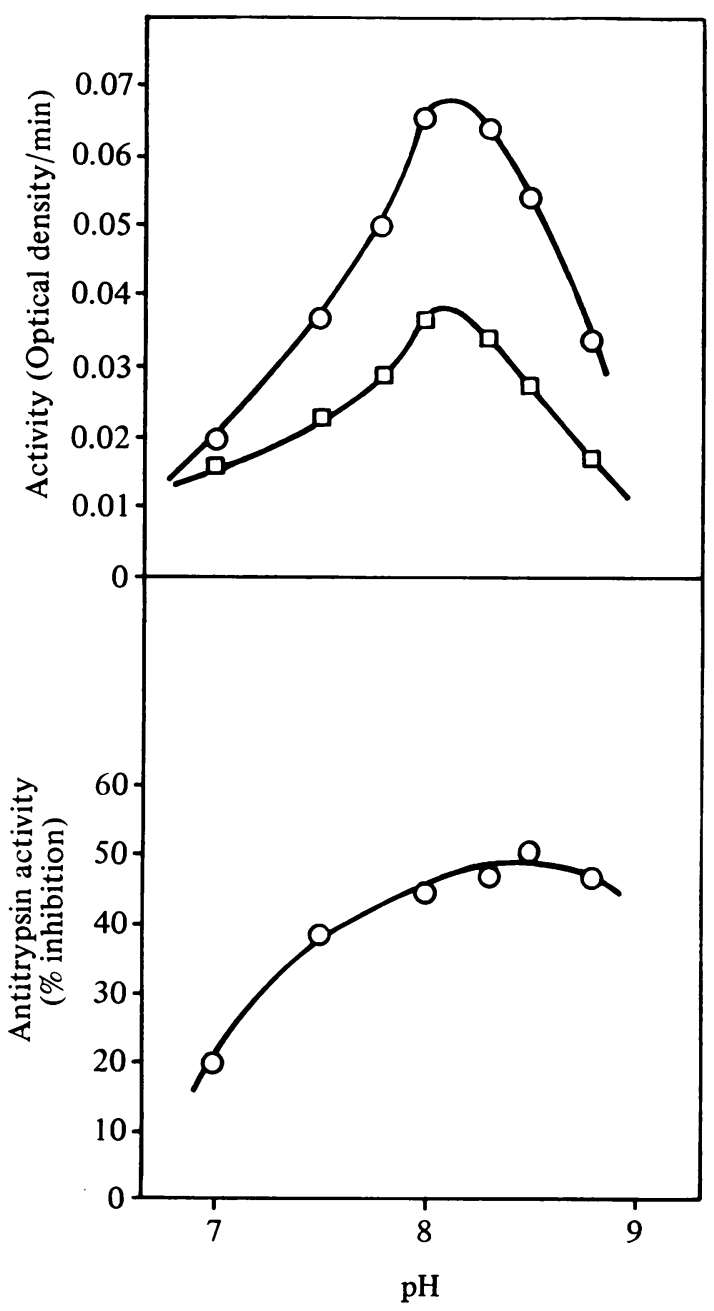

Fig. 1 Effect of $\mathrm{pH}$ on trypsin and serum antitrypsin activity. Trypsin and serum antitrypsin activity were determined as described under Methods, except that $\mathrm{pH}$ was as shown above.
The effect of preincubation of serum with trypsin is shown in Figure 2. Preincubation up to 15 minutes increases the degree of inhibition observed. This phenomenon may be due in part to the requirement for a given steric orientation of the two molecules, a large inhibitor molecule requiring more time to achieve this orientation than a small molecule.

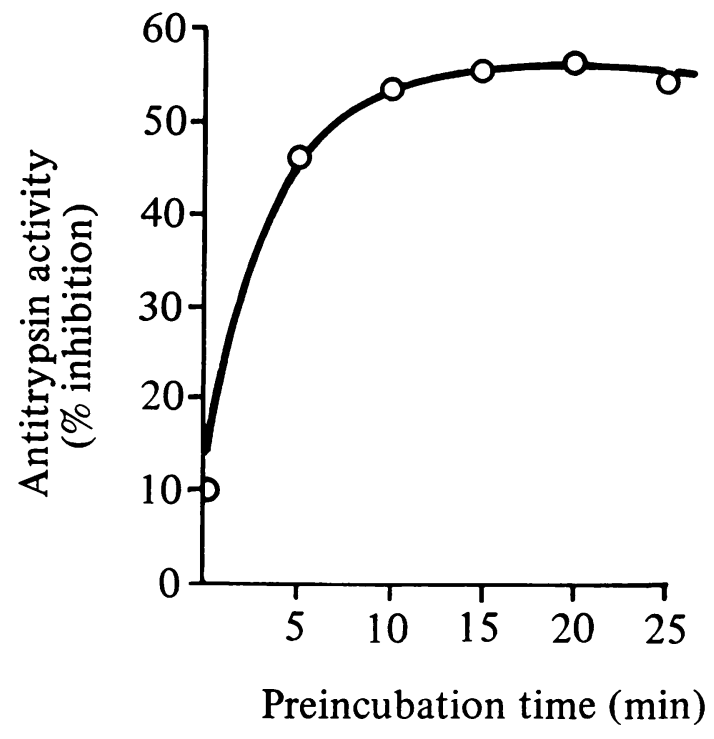

Fig. 2 Effect of preincubation of serum with trypsin on serum antitrypsin activity. The substrate (TAME) was added at the end of the preincubation period shown and the recording of reaction rate begun immediately.

The effect of substrate concentration on trypsin activity and serum antitrypsin activity is shown in Figure 3. For trypsin activity the optimum concentration of TAME is $1.2 \mathrm{mM}$. With increasing TAME concentration from 0.2 to $1.6 \mathrm{mM}$, antitrypsin activity decreases.

The effect of trypsin concentration on antitrypsin activity is shown in Figure 4. With increasing amounts of trypsin, less inhibition is seen with a given amount of serum. The reduction in activity observed with high concentrations of trypsin depends to some extent on the original level of antitrypsin activity in serum. In general, increasing the concentration of trypsin increases accuracy at high levels of antitrypsin activity but decreases accuracy at low levels. Since, from a clinical point of view, estimation of low levels is of more significance, a reduced concentration of trypsin may be advisable for routine testing employing a single trypsin concentration. 


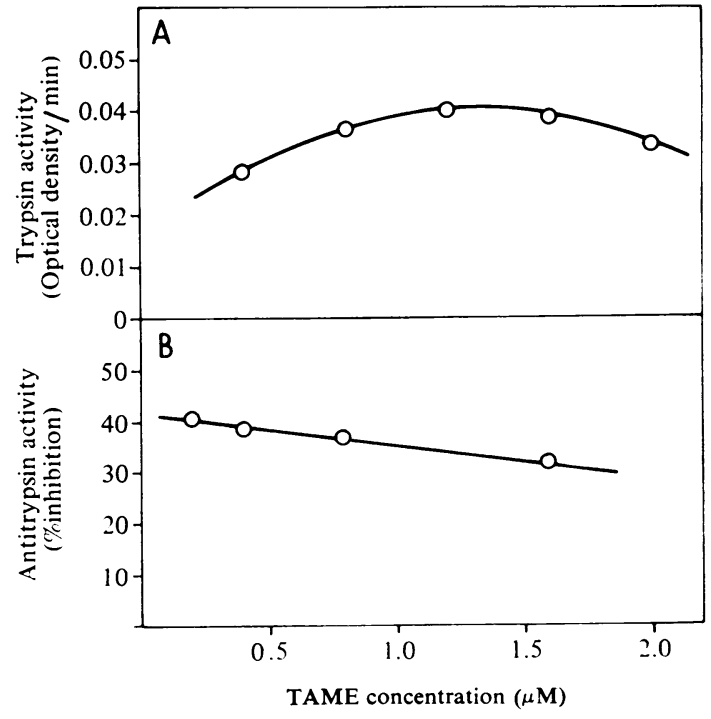

Fig. 3 Effect of substrate concentration on activity of trypsin and antitrypsin.

It should be noted that the low concentrations of serum used in the method described here are not appropriate for all assay methods. In the commonly used method of Eriksson (1965), for example, use of such low concentrations of serum would lead to inaccuracies.

It has been claimed that antitrypsin activity is inversely proportional to the amount of serum used in the assay (Homer, Katchman, and Zipf, 1963; Webb, 1963). The relation is more complex. As shown in Fig. 4, the antitrypsin activity is a sigmoid function of the log of the amount of serum used. The sigmoid character is especially prominent with small amounts of enzyme. The relation is also sigmoid when BAEE is used as substrate, showing that this result is not dependent on the use of the substrate TAME. In addition, it was sigmoid when homozygous deficient $\mathrm{ZZ}$ serum was substituted for $M M$ serum, indicating this to be a property of serum antitrypsin activity not limited to the MM genotype. For a reversible inhibitor, a sigmoid relation is the expected relation whatever the mechanism of inhibition (Eriksson, 1965). In the case of serum inhibition of trypsin, the binding of trypsin by alpha $_{2}$-macroglobulin also contributes to the sigmoid shape (Ganrot, 1967). The Table presents data for the reversibility of serum antitrypsin activity; when, following preincubation, serum and trypsin were diluted, the percentage inhibition observed was related to the amount of dilution.

\begin{tabular}{ll}
\hline $\begin{array}{l}\text { Dilution of } \\
\text { Trypsin and Serum }\end{array}$ & $\begin{array}{l}\text { Percentage } \\
\text { Inhibition }\end{array}$ \\
\hline None & 43 \\
1 in 2 & 22 \\
1 in 4 & 10.5 \\
\hline
\end{tabular}

Table Reversibility of trypsin inhibition by serum

This sigmoid relationship has a practical implication. For a given enzyme concentration with large serum volumes, little difference in antitrypsin activity is seen. The same is true of low serum volumes. Only in the intermediate range is a change in serum volume sensitively reflected by a change in the antitrypsin activity observed.

Above $80 \%$ inhibition, the slope of the curve shown in Fig. 4 is more gradual; to achieve $100 \%$ inhibition in our assay requires approximately $0.1 \mathrm{ml}$ of normal serum. This feature is not readily explained

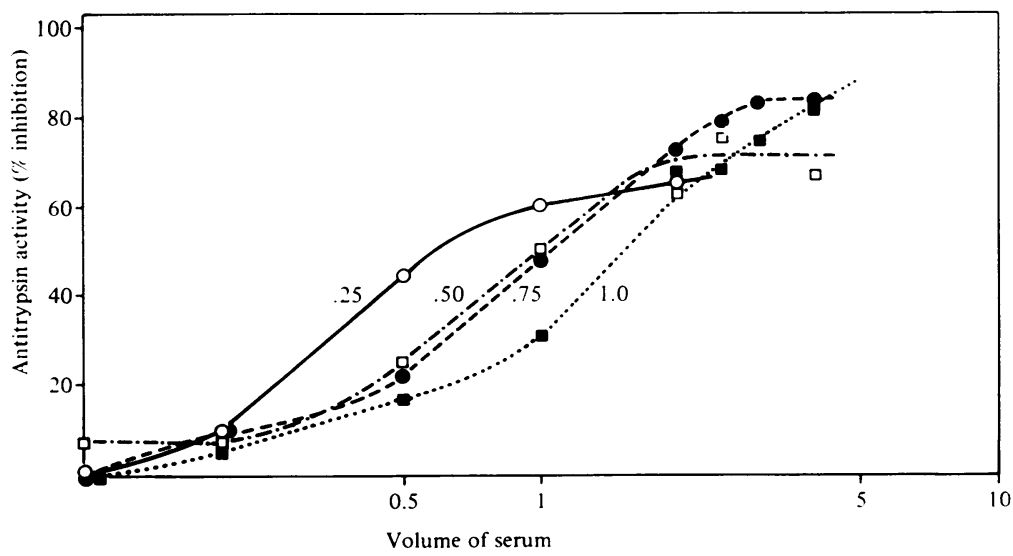

Fig. 4 Effect of serum and trypsin concentrations on serum antitrypsin activity. Complete inhibition is observed only with much larger amounts of serum, about $0.1 \mathrm{ml}$ in this assay. 
by the simplest reversible enzyme-inhibitor model. It may represent the binding of a fraction of the trypsin to alpha $a_{2}$-macroglobulin rather than the alpha $_{1}$-antitrypsin (Haverback, Dyce, Bundy, Wirtschafter, and Edmondson, 1962).

In summary, a sensitive assay for serum antitrypsin activity must take into account the narrow optimal $p \mathrm{H}$ range, the greater activity upon preincubation of serum with trypsin, and the sigmoid relation between the $\log$ of the serum volume and the inhibition observed. Although manipulation of these variables has not permitted consistent distinction between $M M$ and $M Z$ types, work is in progress combining these features with different substrates and with enzymes other than trypsin.

We thank Drs Robert H. Schwartz and D. Robert Webb for generously supplying sera of known genotype and Dr John Crispin Smith for helpful discussions.

\section{References}

Daughaday, C., Eradio, B., and Pierce, J. A. (1971). Proteinase inhibitor phenotypes in Saint Louis. (Presented in part at the Southern Society for Clinical Investigation, January 29).

Eriksson, S. (1965). Studies in $a_{1}$-antitrypsin deficiency. Acta med. scand., Suppl., 432,

Fagerhol, M. K. (1969). Quantitative studies on the inherited variants of serum $a_{1}$-antitrypsin. Scand. J. clin. Lab. Invest., 23, 97-103.

Ganrot, P. O. (1967). Partition of trypsin between $\alpha_{2}$-macroglobulin and the other trypsin inhibitors of serum. Arkiv Kemi, 26, 577-582.

Guenter, C. A., Welch, M. H., and Hammarsten, J. F. (1971). Alpha antitrypsin deficiency and pulmonary emphysema. Ann. Rev. Med., 22, 283-292.

Haverback, B. J., Dyce, B., Bundy, H. F., Wirtschafter, S. K., and Edmondson, H. A. (1962). Protein binding of pancreatic proteolytic enzymes. J. clin. Invest., 41, 972-980.

Homer, G. M., Katchman, B. J., and Zipf, R. E. (1963). A spectrophotometric method for measuring serum trypsin inhibitor capacity. Clin. Chem., 9, 428-437.

Jacobsson, K. (1955). Studies on the trypsin and plasmin inhibitors in human blood serum. Scand. J. clin. Lab. Invest., 7, Suppl. 14, 55-102.

Laskowski, M. K., Jr., and Sealock, R. W. (1971). Protein proteinase inhibitors-molecular aspects. In The Enzymes, ?rd ed., edited by P. D. Boyer, vol. 3, p. 429. Academic Press, New York and London.

Webb, J. L. (1963). Enzyme and Metabolic Inhibitors, vol. 1, p. 62. Academic Press, New York and London. 